\title{
Research on the Development Situation and Optimization Measures of the Construction of the State-Owned Business Environment in China
}

\author{
He JIANG; Yonghui CAO*; Hui LIU \\ Department of Business Administration, Guangzhou College of Technology and Business, Guangzhou, 510850, China \\ *Corresponding author: Yonghui CAO \\ E-mail: xinrui20132015@126.com
}

\begin{abstract}
With the gradual improvement of the socialist market economy system, Reform and Opening up are also deepening and developing. In recent years, our government has done a lot of work in optimizing the business environment, and has made great progress, which has been recognized by the world. Of course, while the overall business environment construction of our country has made positive progress, some reforms have not yet made substantive breakthroughs. Therefore, it is urgent to carry out in-depth reforms, compare with the advanced ones, and reflect on ourselves, so as to enhance the international competitiveness of the business environment of our government in the future.
\end{abstract}

Keywords: business environment, reform, market environment, optimization measures

\section{INTRODUCTION}

At present, China's economy is in the transition stage from medium and high-speed growth to high-quality development, which is also the key period to optimize the economic structure and transform the growth momentum. The economic development in the new era needs a good environment to match it. As an indispensable external environment for the growth of enterprises, business environment is affecting the healthy growth of market subjects, and then affecting the high-quality development of economy [1]. Therefore, paying attention to the construction of business environment is an important factor to ensure the sustainable growth of China's economy. China has carried out many reforms in recent years, hoping to further optimize the business environment through institutional innovation. In 2018, Premier Li Keqiang proposed in the government report that "optimizing the business environment is liberating productivity". It can be said that in the increasingly fierce international competition, optimizing the state-owned business environment can boost the confidence of enterprises, attract foreign investment and promote the sustainable development of the economy. In fact, the construction of business environment has become an important national strategy in China.

\section{EFFORTS AND EXPLORATIONS OF THE STATE- OWNED BUSINESS ENVIRONMENT AT THE POLICY LEVEL}

Looking back on the early stage of reform and opening up, although the concept of business environment has not been clearly mentioned in China, relevant work has been done. Governments at all levels, especially the local governments in coastal open cities, regard the soft environment of business enterprises as an important signboard for attracting investment [2]. Since China's accession to the WTO, China has made a lot of efforts from the policy level and formulated a series of policy measures. For example, in order to attract foreign investment, preferential policies, mainly represented by taxes, have been adopted by many local governments. In the process of economic development, the Chinese government has clearly put forward the goal of the reform of the socialist market economy system, and stimulated the rapid development of various enterprises through various reform measures [3]. With the increasing degree of economic globalization and commercial competition, market entities are more in urgent need of a market environment of fair competition. There is a growing demand for equal treatment among enterprises of different ownership. Especially private enterprises put forward to eliminate the problem of "super national treatment" of foreign-funded enterprises, which should be treated equally at home and abroad. Indeed, the preferential treatment given to foreign-funded enterprises in the early stage of reform and opening up has led to the economic development of our country [4]. In the new era, it is an 
urgent need for more enterprises to establish a transparent and fair market environment.

Since 2002, under the requirements of WTO rules, our government has also carried out a number of market reforms, but the reference to "business environment" rarely appears in the reports of domestic governments at all levels. With the first business environment report issued by the world bank in 2003, the concept of "business environment" has been spread rapidly [5]. Many countries, including developed countries and developing economies, have begun to use business environment to measure the quality of a country's investment environment. Since then, Chinese governments at all levels have gradually begun to accept the concept of "business environment", and the construction of business environment has gradually become the core indicator of the performance appraisal of the superior government to the subordinate government.

The following are the relevant policies and efforts made by our government in the construction of business environment, which shows our firm determination in optimizing business environment:

Table 1 development of business environment at national policy level

\begin{tabular}{|c|c|}
\hline national level & core content \\
\hline $\begin{array}{c}\text { The Third Plenary Session } \\
\text { of the 18th CPC Central } \\
\text { Committee }\end{array}$ & $\begin{array}{l}\text { The decision of the Central } \\
\text { Committee of the Communist Party } \\
\text { of China on several major issues of } \\
\text { comprehensively deepening the } \\
\text { reform first proposed: "building a } \\
\text { legal business environment". }\end{array}$ \\
\hline $\begin{array}{c}\text { The Fifth Plenary Session } \\
\text { of the 18th CPC Central } \\
\text { Committee }\end{array}$ & $\begin{array}{l}\text { "We should form a new system of } \\
\text { opening up to the outside world, and } \\
\text { improve the business environment of } \\
\text { legalization, internationalization and } \\
\text { facilitation.", further enriching the } \\
\text { connotation and objectives of } \\
\text { business environment. }\end{array}$ \\
\hline $\begin{array}{l}\text { In July } 2015 \text {, general } \\
\text { secretary Xi Jinping } \\
\text { revive the old industrial } \\
\text { bases in Northeast China } \\
\text { in Jilin province. }\end{array}$ & $\begin{array}{l}\text { It is emphasized that we should } \\
\text { resolutely remove institutional and } \\
\text { institutional obstacles, adhere to the } \\
\text { direction of socialist market economy } \\
\text { reform, actively discover and } \\
\text { cultivate markets, further simplify } \\
\text { administration and decentralization, } \\
\text { optimize the business environment, } \\
\text { and find ways, steps and solutions } \\
\text { from liberalizing markets. }\end{array}$ \\
\hline $\begin{array}{l}\text { Government work report } \\
\text { on March 5, } 2016\end{array}$ & $\begin{array}{l}\text { We will continue to streamline } \\
\text { administration and delegate power, } \\
\text { integrate decentralization with } \\
\text { management, optimize services, and } \\
\text { improve government effectiveness. }\end{array}$ \\
\hline $\begin{array}{l}\text { Outline of the } 13 \text { th five } \\
\text { year plan for national } \\
\text { economic and social } \\
\text { development, March } 17 \text {, } \\
2016\end{array}$ & $\begin{array}{l}\text { It is proposed to "create a good } \\
\text { business environment". }\end{array}$ \\
\hline $\begin{array}{c}\text { On May 23, 2016, } \\
\text { The State Council printed } \\
\text { and distributed the key } \\
\text { points of } 2016 \text { work to } \\
\text { promote the reform of } \\
\text { streamlining } \\
\text { administration, delegating }\end{array}$ & $\begin{array}{l}\text { We will promote reform by } \\
\text { streamlining administration, } \\
\text { delegating authority, delegating } \\
\text { control, and optimizing services. }\end{array}$ \\
\hline
\end{tabular}

\begin{tabular}{|c|c|}
\hline $\begin{array}{l}\text { powers, combining } \\
\text { management and } \\
\text { optimizing services }\end{array}$ & \\
\hline $\begin{array}{l}\text { On June } 13,2017 \text {, Premier } \\
\text { Li Keqiang held a } \\
\text { teleconference on } \\
\text { deepening the reform of } \\
\text { deregulation service. }\end{array}$ & $\begin{array}{l}\text { Make an important conclusion that } \\
\text { "business environment } \\
\text { productivity". He pointed out that all } \\
\text { localities should not only actively } \\
\text { focus on project construction, but } \\
\text { also on environmental construction. } \\
\text { Instead of pursuing preferential } \\
\text { policies "lowland" in the past, they } \\
\text { should build a "highland" of a fair } \\
\text { business environment, and truly } \\
\text { achieve simpler approval, stronger } \\
\text { supervision and better service. }\end{array}$ \\
\hline $\begin{array}{l}\text { On June } 28,2018, \text { the } \\
\text { State Council held a } \\
\text { teleconference on } \\
\text { deepening the reform of " } \\
\text { deregulation service " and } \\
\text { transforming the functions } \\
\text { of the government. }\end{array}$ & $\begin{array}{l}\text { Further clarify the objectives and } \\
\text { tasks of business environment reform } \\
\text { in terms of streamlining } \\
\text { administration and delegating power, } \\
\text { innovating supervision and } \\
\text { optimizing services. }\end{array}$ \\
\hline $\begin{array}{l}\text { In July 2018, the State } \\
\text { Council launched a } \\
\text { comprehensive inspection. }\end{array}$ & $\begin{array}{l}\text { It is emphasized that the reform of } \\
\text { business environment should speed } \\
\text { up the implementation of the } \\
\text { requirements of "five for" and "six } \\
\text { one". }\end{array}$ \\
\hline $\begin{array}{l}\text { In October } 2019 \text {, } \\
\text { regulations on optimizing } \\
\text { business environment was } \\
\text { issued and implemented in } \\
\text { January } 2020 .\end{array}$ & $\begin{array}{l}\text { We will continue to optimize the } \\
\text { business environment, emancipate } \\
\text { and develop social productivity, } \\
\text { accelerate the construction of a } \\
\text { modern economic system, and } \\
\text { promote high-quality development. }\end{array}$ \\
\hline
\end{tabular}

From the relevant policies formulated by our government and the reform process of business environment in recent years, we can see that our country attaches great importance to the construction of business environment. At the central level, the improvement and optimization of the business environment have been promoted and strengthened. Local governments, following the spirit of the central government, have made beneficial explorations and attempts for the construction of the business environment based on local conditions, stimulated the enthusiasm and innovation vitality of the market subjects, and laid an environmental foundation for the high-quality development of China's economy.

\section{THESIGNIFICANCE OF OPTIMIZING BUSINESS ENVIRONMENT LEGISLATION}

In order to actively and effectively promote the construction of business environment, on October 22, 2019, the Chinese government initiated legislation for the optimization of business environment.

The regulations on optimizing business environment issued this time is a pioneering system innovation work in China from the perspective of system. Looking around the world, there are very few countries or regions that carry out business environment construction from the legislative level. The only ones are some improvement measures and implementation arrangements related to business 
environment, which have not yet risen to the height of legislation. The promulgation of the regulations on the optimization of business environment is to sort out and summarize the policies and practices of various regions in the business environment through the system level, and its content is more strategic, normative and systematic. The regulations are fixed in legal form and can enable all regions to carry out their work orderly under the guidance of the State Council's business environment policy. At the same time, the regulations also strengthen the legal binding force of business environment construction, which is the guideline for each region to carry out relevant work, and provides strong support and guarantee for optimizing business environment from the legal level, which has important practical value. In addition, the regulations further enhance the enthusiasm of all regions to optimize the business environment, enhance the awareness of all levels of governments in the business environment related work, emancipate the mind, break and reform the ideological barriers in the business environment construction. It will play a fundamental and lasting role in boosting the confidence of market subjects, creating a high-quality social environment for development, and stabilizing the expectation of economic development.

\section{KEY MEASURES TO OPTIMIZE BUSINESS ENVIRONMENT}

\section{1 protect the interests of market subjects and create a good market environment}

First of all, we should strengthen the equal protection of market players. The regulations on optimizing the business environment clearly points out that the government adheres to the principle of equality for all kinds of ownership economy, including equal rights, rules and opportunities, guarantees the equal status of all kinds of market subjects in the business process, and implements the fair treatment of market subjects. It mainly includes the following aspects: First, treat all kinds of market subject status equally. In the regulations, it is clear that the state protects the equal treatment of market subjects according to law, such as in the use of various elements, bidding, policy support and government procurement, so as to provide legal support for all kinds of market subjects to participate in fair competition. Second, we should protect the legitimate rights and interests of market subjects and increase the protection of intellectual property rights. The regulations legislate from the aspects of the operation autonomy and property rights of the market subjects, and protect the legitimate interests of the market subjects and legal persons. We should establish the system of intellectual property protection, put forward the punishment measures of intellectual property protection, and prevent intellectual infringement. Third, we should actively provide legislative basis for market subjects to safeguard their rights. In order to ensure that the market subjects can effectively and conveniently protect the rights of the problems in the business process, the regulations put forward to speed up the construction of the rights protection platform, so that the market subjects can quickly safeguard the rights on the national unified service platform and obtain the corresponding economic benefits. Secondly, create a good market environment. The regulations on the optimization of business environment focuses on solving the difficult problems encountered by various market subjects in the process of business operation, creating a fair market environment, solving various business obstacles caused by imperfect systems, etc., so as to better stimulate the enthusiasm of market subjects and enhance the vitality of economic development. First, we need to solve the problem of market entry and exit. In terms of market access, it further clarified the reform of commercial system, actively promoted the separation of certificates and licenses, relaxed market access, and shortened the time for starting enterprises, so that market subjects could start businesses and carry out business activities quickly. On the issue of market exit, the regulation proposes to simplify the cancellation process, simplify or reduce the procedures, materials, time, cost and other aspects, so as to solve the problem of "difficult exit". Second, further implement the issue of tax reduction and fee reduction. From the report of the world bank, it is found that the score of state-owned business environment in terms of tax indicators is not optimistic. In the regulations, various tax reduction and fee reduction policies are made clear, and strict restrictions are imposed on the establishment of enterprise related fees, so as to effectively guarantee that the preferential tax policies benefit enterprises and reduce the business cost of enterprises and other market entities. Third, solve the financing problem. In the process of business operation, financing has become a major problem for market players, especially for private enterprises. The regulations explicitly encourage financial institutions to support small and medium-sized enterprises and private enterprises, prohibit the discriminatory requirements of establishing financing, and practically meet the financing needs of enterprises in operation.

\section{2 improve the service level of government affairs and promote the reform of government affairs system}

In recent years, with the continuous deepening of "deregulation service" reform, the level of government services has been significantly improved, but in some aspects, there is still room for improvement of government services. In order to consolidate the existing reform achievements, reduce unnecessary administrative examination and approval, we are committed to building a fair, just, transparent and efficient government system, and improving the level and quality of the government's service for the market main body. The regulations on optimizing business environment mainly make relevant 
regulations and efforts from the following aspects: first, standardize the management of government services. This mainly means that in the process of serving market subjects such as enterprises, the government should work out standardized workflow and relevant guidelines, and build a standardized government service system, so as to reduce unnecessary links of market subjects in the process of handling relevant government affairs. Second, we should improve the efficiency of government administration in terms of time, number of procedures and handling methods. The government actively promotes immediate, nearby, one-time and online processing methods, and strives to build a national integrated online government service platform, share government service information, and use various business start-up methods such as electronic certificates to simplify relevant paper-based procedures, so as to make business processing activities easier and faster. Third, reform the administrative examination and approval system. Through integration and other ways, the government optimizes the administrative examination and approval procedures, streamlines the handling links, and practically improves the business experience of market entities such as enterprises in the process of administrative examination and approval. Fourth, carry out facilitation reform in key administrative service areas. For example, for administrative services in key areas such as construction license, electric power handling, tax payment, property registration, etc., the government should put forward facilitation measures, break the mechanism barriers related to the economic activities of market subjects, and create a first-class business environment level.

\section{3 standardize the government supervision mode and promote the standardization of law enforcement}

It is also an important part of the regulations on optimizing the business environment to regulate the government's supervision mode, maintain the market order and guarantee the fair competition in the business process. In order to provide standardized law enforcement for the business activities of the market subjects involved in the business process, avoid the influence of too much supervision on the development of enterprises, and the negative deviation caused by too little supervision, it is necessary to standardize the law enforcement and supervision system. First, law enforcement mechanism innovation. We will implement comprehensive administrative law enforcement, establish a law enforcement linkage mechanism, and improve law enforcement response. Through the transition from independent law enforcement to comprehensive law enforcement by the regulatory authorities, the law enforcement burden on enterprises and other market entities caused by unnecessary and excessive inspections will be reduced, so as to achieve a comprehensive inspection and the overall law enforcement effect of physical examination. Second, the reform of supervision mode. The government has implemented a "double random and one open" supervision, actively utilizing the regulatory convenience brought by the Internet, and implementing the new supervision mode of "Internet + regulation". The government focuses on the supervision of special areas involving public interests and life safety, and includes prudent supervision of emerging industries. Third, standardize law enforcement. We should be careful in implementing administrative coercion, and should not arbitrarily take law enforcement measures such as stopping production or business for the market subjects, reduce excessive interference to the market subjects' business activities, and standardize the scope and range of administrative law enforcement.

\section{4 strengthen the legal guarantee of business and enhance the scientificity of laws and policies}

The guarantee of rule of law is very important to optimize the implementation of business environment, and it is the legal basis for the implementation of various policies of business environment. The regulations clearly stipulate the construction of the government's rule of law around the laws and policies of the business environment. In view of the deficiencies in the formulation and implementation of business environment policies, the transparency and stability of the policies are proposed, which strengthens the confidence of enterprises and other market entities in the continuous stability of the policy environment. The main construction of the business rule of law system is as follows: first, enhance the participation and transparency of the relevant rule of law policy-making. Because the construction of business environment and rule of law is ultimately to protect the market subjects, we should actively listen to their opinions when making policies, so that the laws and regulations formulated can be more in line with business practice. In addition, in addition to the relevant confidential documents, the solicitation of opinions should be made public to increase transparency. Second, ensure the scientific implementation of laws and policies. When introducing new laws and regulations, we should consider the transition period of market subjects in accordance with the new laws and regulations, and reserve some buffer space for them. Third, actively carry out the publicity of laws and policies related to enterprises. We can adopt various forms and ways to publicize and popularize laws and regulations related to business environment, so that more market subjects can know, understand and use laws, so as to protect their economic interests.

\section{CONCLUSION}

To sum up, by analyzing the development of China's state-owned business environment in recent years, we can 
be sure that our government has done a lot of work in optimizing the business environment and made great progress, which has been recognized by the world. Especially in the past three years, China's central government and the State Council have attached great importance to the top-level design of business environment construction, introduced relevant laws and regulations, and encouraged the confidence of enterprise management. In particular, the regulations on the optimization of business environment issued in 2019 has raised the construction of business environment to a legislative level, which shows the determination of our government on this work. Of course, while the overall business environment construction of our country has made positive progress, some reforms have not yet made substantive breakthroughs. Therefore, it is imperative to carry out reforms in depth and to compare ourselves with advanced reforms.

\section{ACKNOWLEDGMENT}

This work was financially Sponsored by The 13th five year plan of Education Science in Guangdong Province, 2019 University Philosophy and Social Sciences special research project, the research area of one belt, one road and one big area in Guangdong Bay, Hong Kong and Macao, Serial number 21.

\section{REFERENCES}

[1] Carlin W, Seabright P. Bring Me Sunshine: Which Parts of the Business Climate Should Public Policy Try to Fix?[J]. ABCDE, 2009: 99-110.

[2] Corcoran A, Gillanders R. Foreign direct investment and the ease of doing business[J]. Review of World Economics, 2015, 151(1): 103-126.

[3] Doing business group of the World Bank. Doing Business 2020. https://chinese.doingbusiness.org/

[4] Klapper L, Lewin A, Delgado J M Q. The impact of the business environment on the business creation process $[\mathrm{M}] / /$ Entrepreneurship and Economic Development. Palgrave Macmillan, London, 2011: 108-123.

[5] Ward P T, Duray R, Leong G K, et al. Business environment, operations strategy, and performance: an empirical study of Singapore manufacturers[J]. Journal of operations management, 1995, 13(2): 99-115. 